\title{
Az országos zöldinfrastruktúra-hálózat kijelölésének módszertana többszempontú állapotértékelés alapján
}

\author{
Szitár Katalin, Csőszi Mónika², Vaszócsik Vilja², Schneller \\ Krisztián ${ }^{2}$, Csecserits Anikó ${ }^{3}, K_{\text {Kollányi László }}^{4}$, Teleki Mónika ${ }^{2}$, \\ Kiss Dániel $^{2}$, Bánhidai András ${ }^{2}$, Jáger Katalin² ${ }^{2}$, Petrik Ottó ${ }^{2}$, Pataki \\ Róbert $^{2}$, Lehoczki Róbert ${ }^{2}$, Halassy Melinda ${ }^{3}$, Tanács Eszter ${ }^{3}$, \\ Kertész Miklós ${ }^{3}$, Csákvári Edina ${ }^{3}$, Somodi Imelda ${ }^{3}$, Lengyel Attila ${ }^{3}$, \\ Gallé Róbert ${ }^{1}$, Weiperth András ${ }^{5}$, Konkoly-Gyuró Éva ${ }^{6}$, Máté \\ Klaudia ${ }^{4}$, Keszthelyi Ákos Bence ${ }^{4}$ és Török Katalin ${ }^{3}$ \\ ${ }^{1}$ Ökológiai Kutatóközpont, Ökológiai és Botanikai Intézet, Lendület Táj és \\ Természetvédelmi Ökológiai Kutatócsoport, 2163 Vácrátót, Alkotmány u. 2-4. \\ ${ }^{2}$ Lechner Tudásközpont Nonprofit Kft., \\ 1111 Budapest, Budafoki út 59., 1149 Budapest, Bosnyák tér 5. \\ ${ }^{3}$ Ökológiai Kutatóközpont, Ökológiai és Botanikai Intézet, \\ 2163 Vácrátót, Alkotmány u. 2-4. \\ ${ }^{4}$ Ormos Imre Alapítvány, 1118 Budapest, Villányi út 29-43. \\ ${ }^{5}$ Magyar Agrár-és Élettudományi Egyetem, Akvakultúra és Környezetbiztonsági Intézet, \\ Természetesvizi Halökológiai Tanszék, 2100 Gödöllö, Páter Károly u. 1. \\ ${ }^{6}$ Soproni Egyetem, Környezet-és Földtudományi Intézet, \\ 9400 Sopron, Bajcsy-Zsilinszky u. 4. \\ E-mail:szitar.katalin@ecolres.hu
}

Összefoglaló: Az EU Biodiverzitás Stratégiájában szereplő zöldinfrastruktúra koncepció szerint a biodiverzitás megőrzése úgy biztosítható, ha a természetközeli élőhelyek és az egyéb, ökológiai funkciót betöltő, de nem természetközeli tájalkotó elemek (pl. telepített fasorok, gyepes mezsgyék) müködő, azaz az élővilág számára átjárható élőhelyhálózattá kapcsolódnak össze. Vizsgálatainkban ezért három szempont, az ökológiai állapot, a térbeli összekapcsoltság és a multifunkcionalitás alapján értékeltük hazánk ökoszisztémáit. Az értékelés szerint jelenleg az ország 49\%-a tekinthető a zöldinfrastruktúra-hálózat részének, de a lehatárolt zöldinfrastruktúra-hálózatnak mindössze 10\%-a van kiváló ökológiai állapotban. A többi terület indikátorértékei alkalmasak azon intézkedések meghatározására, amelyek javítják az ökoszisztémák állapotát, térbeli összekötöttségét, amivel az emberi jóllét szintjét is növelik.

Kulcsszavak: effektív hálóméret, erózióvédelem, fragmentáció, konnektivitás, lefolyás-mérséklés, pollináció, rekreáció, természetesség 


\section{Bevezetés}

Az antropogén tájátalakítás a természetközeli élőhelyek feldarabolódását és degradációját, a biodiverzitás és az ökoszisztéma-szolgáltatások (továbbiakban ÖSZ) romlását eredményezi világszerte (Foley et al. 2005; Schröter et al. 2005). Az elsősorban védett területek megőrzésére alapozott természetmegőrzés korlátozott hatékonyságát felismerve adoptálták a zöldinfrastruktúra koncepcióját egész tájak, régiók területére (COM[2011] 244 EB, COM[2013] 249 EB), amelynek átfogó szempontjai beépülhetnek a területi és települési tervezésbe, valamint a különböző ágazatok szempontrendszerébe és tervezési gyakorlatába.

A koncepció a magas természeti értékü területek mellett a természetvédelmi szempontból hagyományosan kevésbé értékesnek tartott területek értékeit, funkcióit is figyelembe veszi. Mivel minden területet befolyásol valamilyen jellegü gazdasági (pl. mezö-, erdő-, víz- vagy városgazdálkodási) tevékenység, ezért ezeket integrálni igyekszik az értékelés és a fejlesztési lehetőségek meghatározása során. Ezzel egy koherens, térben összefüggő, többfunkciójú rendszerként tekint a tájra, amelyben az ökológiai funkciók és értékek mellett a gazdasági és társadalmi szempontból fontos ökoszisztéma-szolgáltatásokat is szem elött tartja.

A koncepciónak számos definíciója létezik. Hazánkban eddig a legszélesebb szakmai kör javaslata alapján (Csőszi et al. 2021) zöldinfrastruktúrának (a továbbiakban $\mathrm{ZI}$ ) nevezzük ,a természetes és természetközeli állapotú területek, valamint az ökológiai funkciót betöltő egyéb, növényzettel fedett területek, illetve vizek és vízparti ökoszisztémák hálózatát. A ZI területek multifunkcionális erőforrások, amelyek sokoldalú ÖSZ-ek biztosítására képesek. Az ÖSZ-ek fenntartása, fejlesztése a ZI - fenntarthatóság alapelvei szerint történő - stratégiai tervezésével, fejlesztésével és kezelésével biztosítható. A ZI a vidéki és városi környezetben egyaránt jelen van.”

A fenti definíció alapján a három fő szempont, amellyel egy zöldinfrastruktúra-elem állapota jellemezhető, az ökológiai állapot, a térbeli összekapcsoltság és a multifunkcionalitás (Liquete et al. 2015). Az ökológiai állapot annál jobbnak tekinthető, minél inkább természetes önfenntartó folyamatok érvényesülnek, minél kevesebb antropogén zavarás éri a rendszert, és minél nagyobb őshonos biodiverzitással rendelkezik (vö. ökológiai integritás, De Leo és Levin 1997). A térbeli összekapcsoltság azt mutatja meg, hogy az élőlények számára a táj menynyire átjárható, és ezen keresztül a populációk túlélése, a változó környezethez való alkalmazkodás mennyire lehetséges. A zöldinfrastruktúra értékét alapvetően meghatározza, hogy milyen és hányféle, az ember számára fontos funkciót és javakat biztosít, amelyeket az ÖSZ-ekkel jellemzünk. 
Hazánk „A közösségi jelentőségü természeti értékek hosszú távú megőrzését és fejlesztését, valamint az EU Biológiai Sokféleség Stratégia 2020 célkitüzéseinek hazai szintủ megvalósítását megalapozó stratégiai vizsgálatok" címü KEHOP4.3.0-VEKOP-15-2016-00001 számú kutatási projekt Zöldinfrastruktúra fejlesztési elemének keretében alapozta meg a hazai ZI-hálózat kijelölésének, értékelésének és fejlesztésének módszertanát. E cikk keretében bemutatjuk azt a hármas szempontrendszert, amely a ZI-hálózat kijelölésének és értékelésének alapját adja.

\section{Anyag és módszer}

A ZI alapállapot-értékeléshez szükséges adatokat már rendelkezésre álló információk adták, további új, elsődleges adatgyüjtés nem történt. A projekt Ökoszisztéma-alaptérképét használtuk bemeneti térképként, amely az ország teljes területére rendelkezésre álló, $20 \mathrm{~m} \times 20 \mathrm{~m}$-es térbeli felbontású raszteres térkép, és amely háromszintü, felszínborítás-alapú ökoszisztéma-kategória beosztással rendelkezik (Tanács et al. 2019). Az ökológiai állapot és a multifunkcionalitás értékelése nagyrészt a projekt Ökoszisztéma-szolgáltatások fejlesztési elemének eredményein alapul (Kovács-Hostyánszki et al. 2019; Tanács et al. 2021, míg a térbeli összekapcsoltság indikátorait a ZI fejlesztési elemen belül dolgoztuk ki (Csőszi et al. 2020). A felhasznált indikátorokból három darab ötfokozatú indikátort, valamint egy ezeket összesítő kompozitindikátort képeztünk.

Az első indikátor az ökológiai állapot, amelynek alapját a MÉTA (Magyarország Élőhelyeinek Térképi Adatbázisa) növényzeti természetesség értékelése adta (Bölöni et al. 2011), amihez hasonlóan a leginkább átalakított élőhelytípusok 1-es (rossz) vagy 2-es (kedvezőtlen), míg a természetközeli élőhelyek 3-as (közepes), 4-es (jó) vagy 5-ös (kiváló) értéket kaptak szakértői döntésünk alapján (1. Online Függelék). Az ökológiai állapotértékeket részben a projekt ökoszisztéma-állapotértékelés indikátorai (Tanács et al. 2021), részben a Vízgyüjtő-gazdálkodási Terv (OVF 2016) eredményei alapján finomítottuk, míg a bizonytalanabb és vélhetöen diverzebb tartalmú ökoszisztéma-kategóriákat (pl. máshová be nem sorolható fásszárú növényzet) egységesen (azaz kategóriánként egyetlen értékkel) értékeltük szakértői döntések alapján az 1. Online Függelék szerint.

A második indikátor a térbeli összekapcsoltság, amelyet három index integrálásával alkottunk meg. Az első egy táji strukturális konnektivitás index, amely megmutatja, hogy egy adott maximális távolságra terjedni képes élőlény számára egy-egy pont környezetében mennyi különböző mértékben átjárható élőhely áll rendelkezésre, súlyozva a fókuszponttól vett távolságukkal. A második index az „effektív hálóméret” index, amely a terjedési akadályok, az utak, vasutak hatásait 
emeli ki, megmutatva, hogy ha a meglévő utak egyenletes rácshálóban helyezkednének el, mekkora lenne az átlagos fragmentációmentes terület mérete (EEA 2011; 2. Online Függelék). A kompozithoz a két indexet normálásukat követően átlagoltuk. Ezek mellett a vízfolyások és állóvizek konnektivitásának becslésére használtuk a harmadik indexet, a Vízgyüjtő-gazdálkodási Terv víztestkategória szerinti beosztását, ami a hossz- és keresztirányú átjárhatóság szempontjait is figyelembe veszi (OVF 2016). A mesterséges víztestek 1-es, az erősen módosítottak 3-as, a természetes víztestek 5-ös indexértéket kaptak. A víztestek (víztestmérettől függő 20 vagy $80 \mathrm{~m}$-es) pufferterülete szintén a víztest összekapcsoltsági értékét kapta meg.

A harmadik indikátorhoz, a multifunkcionalitáshoz, a projekt által értékelt szabályozó/fenntartó és kulturális ÖSZ-ek közül azokat az ÖSZ-eket választottuk ki, amelyeket országosan térképezni lehetett (Kovács-Hostyánszki et al. 2019). A hat kiválasztott ÖSZ indikátorai a következők voltak: éves effektív csapadék (Koncz et al. 2021), vadméhek általi beporzási potenciál (Kovács-Hostyánszki et al. 2021), tényleges erózió elleni védelem, potenciális lefolyás-mérséklés, diffúz tápanyagterhelések szabályozása (Vári et al. 2021) és a gyalogos természetjáró élőhely-preferenciája (Csákvári et al. 2021). Az indikátorokat maximum értékükkel való normálást követően átlagoltuk (Maes et al. 2015), és ezek alkották a külterületi multifunkcionalitás értékelésének alapját. A települések esetében országos kiterjedésben csak a zöldfelületi arányra és a növényzet mennyiségére utaló állapotindikátorok álltak rendelkezésre (belterületek zöldfelületi aránya, egy főre jutó zöldfelület, belterületek fásítottsága, NDVI [Normalizált Vegetációs Index] átlag a belterületeken, fás területek aránya a belterületek 100 m-es szegélyein). Ezekböl az indikátorokból normálást és átlagolást követően készítettünk egy proxy indikátort, amely az állapot alapján közvetve utal a települések multifunkcionalitására. A számítások részleteit lásd a 3. Online Függelékben.

A három indikátort ezután együtt értékeltük (hármas kompozit). Ez az összesített értékelés megmutathatja, hogy a fenti szempontok, mint tengelyek alkotta térben egy-egy terület hol helyezkedik el, azaz milyen állapotban van, és a jelenlegi zöldinfrastruktúra részének tekinthetjük-e (1. ábra). Meghatározhatóak azok a területek, amelyek ökológiai állapotuk, illetve az ÖSZ alapján már jelenleg is működő ZI-elemnek tekinthetők. Mivel a három indikátor összes kombinációja túl sok variációt alkotott volna, ezért a térbeli összekapcsoltság kettő, a multifunkcionalitás három kategóriára egyszerüsítve szerepelt az együttes értékelésben. A hármas értékelés alapján ZI-elemnek tekintettük az összes vízfolyást (azokat is, amelyekről nem állt rendelkezésre állapotadat), az összes közepes, jó és kiváló (3-5) ökológiai állapotú területet, a gyenge (2) ökológiai állapotú területek közül a közepes vagy jelentős, illetve a rossz ökológiai állapotú területek közül a jelentős ökoszisztéma-szolgáltatást nyújtó területeket. 


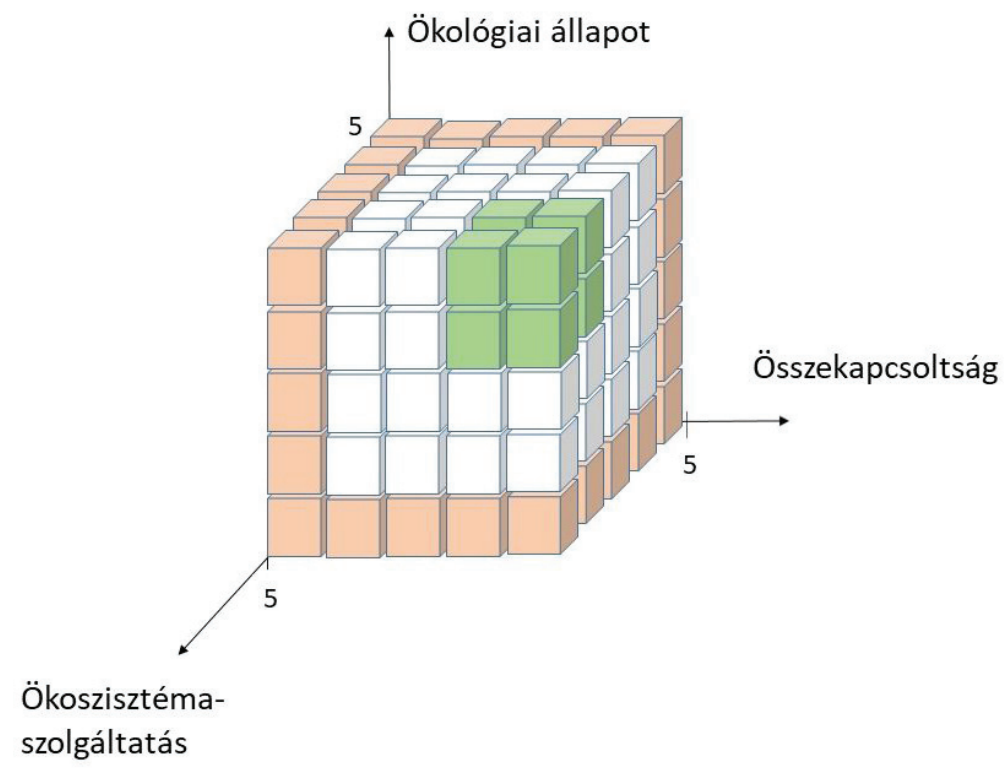

1. ábra. A zöldinfrastruktúra állapotértékelésének három fő tengelye, amelyek megmutatják egyegy zöldinfrastruktúra-elem ökológiai állapotát, ökoszisztéma-szolgáltatásainak szintjét és térbeli összekapcsoltságát. A zöld térrész jelzi azoknak az elemeknek a helyét, amelyek minden szempontból jó állapotúak, míg a piros részeken helyezkednek el azok az elemek, amelyek egy vagy több szempontból rossz állapotúak és fejleszthetők.

\section{Eredmények}

Az ökológiai állapotindikátor alapján hazánk területének közel fele (48,6\%-a) rossz, közel harmada (29,6\%-a) közepes, míg mindössze nem egészen 10\%-a jó vagy kiváló ökológiai állapotú (1. táblázat, 2. ábra). A rossz ökológiai állapotú területek 97\%-a, mintegy 4,4 millió hektár agrárterület. A kedvezötlen ökológiai állapotú területek 51\%-a mesterséges környezetben elhelyezkedő zöldfelület, míg $18 \%$-a fás ültetvény vagy felújítás alatt álló erdőterület. A közepes ökológiai állapotú területek 68\%-a erdőterület és 19\%-a gyep. A jó állapotú területek 68\%-a szintén erdőterület, de ide tartozik a vizes élőhelyek $20 \%$-a és a vizek $46 \%$-a. A kiváló állapotú területek 64\%-a gyep, 19\%-a erdő, míg 16\%-a vizes élőhely.

Eredményeink alapján hazánk területének 29,8\%-a rossz vagy kedvezőtlen térbeli kapcsolatokkal rendelkezik. Közel 4,2 millió hektárnyi területen a térbeli kapcsoltságot közepesnek, míg negyedén jónak vagy kiválónak értékeltük. A 3. ábrán látható, hogy városaink és az azokat összekötő vonalas elemek, utak jelentősen fragmentálják az ország területét. 
1. táblázat. Hazánk különböző ökológiai állapotú, térbeli kapcsoltságú és ökoszisztéma-szolgáltatású területeinek kiterjedése a zöldinfrastruktúra ötfokozatú értékelése alapján. A mesterséges felszínek ökológiai állapotát nem értékeltük.

\begin{tabular}{cccccccc}
\hline Indikátor & Terület & \multicolumn{7}{c}{ Indikátorérték } \\
& & 1 & 2 & 3 & 4 & 5 & nem \\
& & & & & & & értékelt \\
\hline Ökológiai állapot & hektár & 4523105 & 795214 & 2746391 & 441246 & 460380 & 334651 \\
& $\%$ & 48,6 & 8,6 & 29,6 & 4,7 & 4,9 & 3,6 \\
$\begin{array}{c}\text { Térbeli } \\
\text { összekapcsoltság }\end{array}$ & hektár & 520124 & 2252746 & 4195113 & 1383021 & 949983 & \\
$\begin{array}{c}\text { Ökoszisztéma- } \\
\text { szolgáltatás }\end{array}$ & $\%$ & 5,6 & 24,2 & 45,1 & 14,9 & 10,2 & \\
& hektár & 3585393 & 2312503 & 1646303 & 1073688 & 683100 & \\
\hline & $\%$ & 38,6 & 24,9 & 17,7 & 11,5 & 7,3 & \\
\hline
\end{tabular}

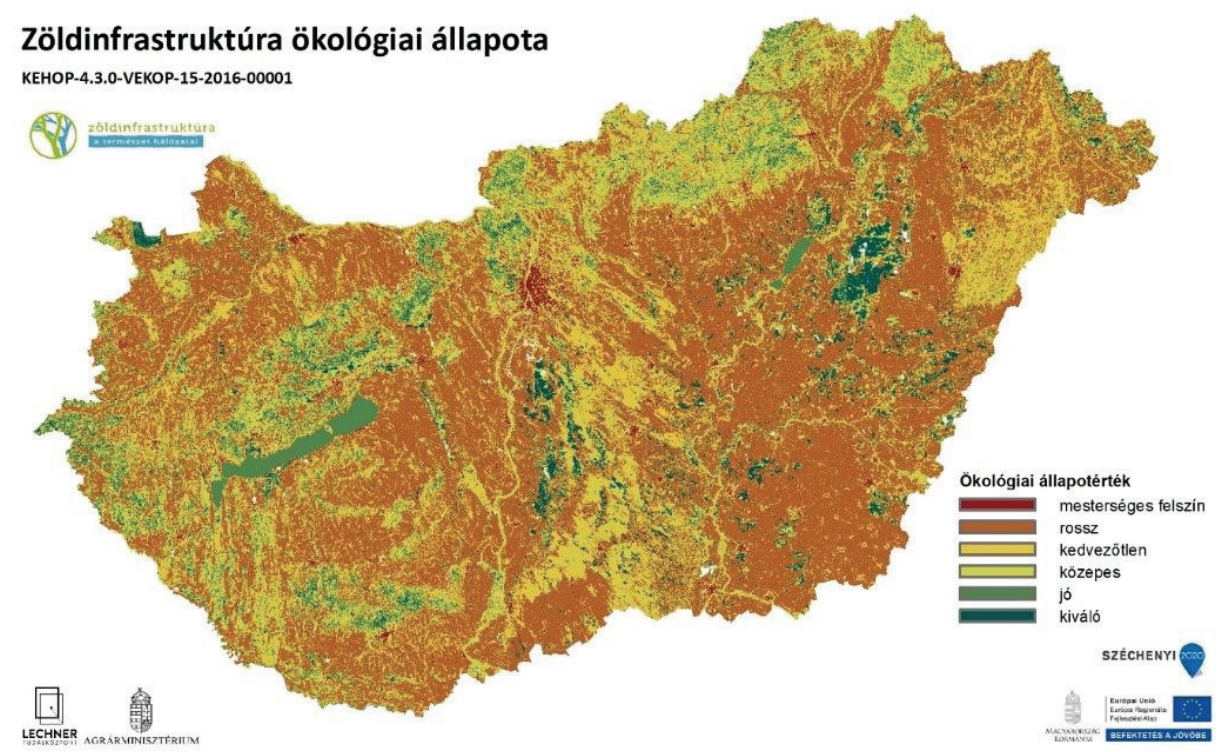

2. ábra. Hazánk ökológiai állapota a zöldinfrastruktúra-értékeléshez kialakított ötfokozatú skálán. A mesterséges felszíneket nem értékeltük.

Elemzésünk szerint az ország területének közel kétharmadán rossz vagy kedvezőtlen, míg csak kevesebb, mint ötödén jó vagy kiváló az ökoszisztéma-szolgáltatások szintje (4. ábra). A 4. ábrán látható, hogy a magasabb szolgáltatás-értékek a dombvidéki és hegyvidéki területekre koncentrálódnak. Ez nem jelenti feltétlenül 


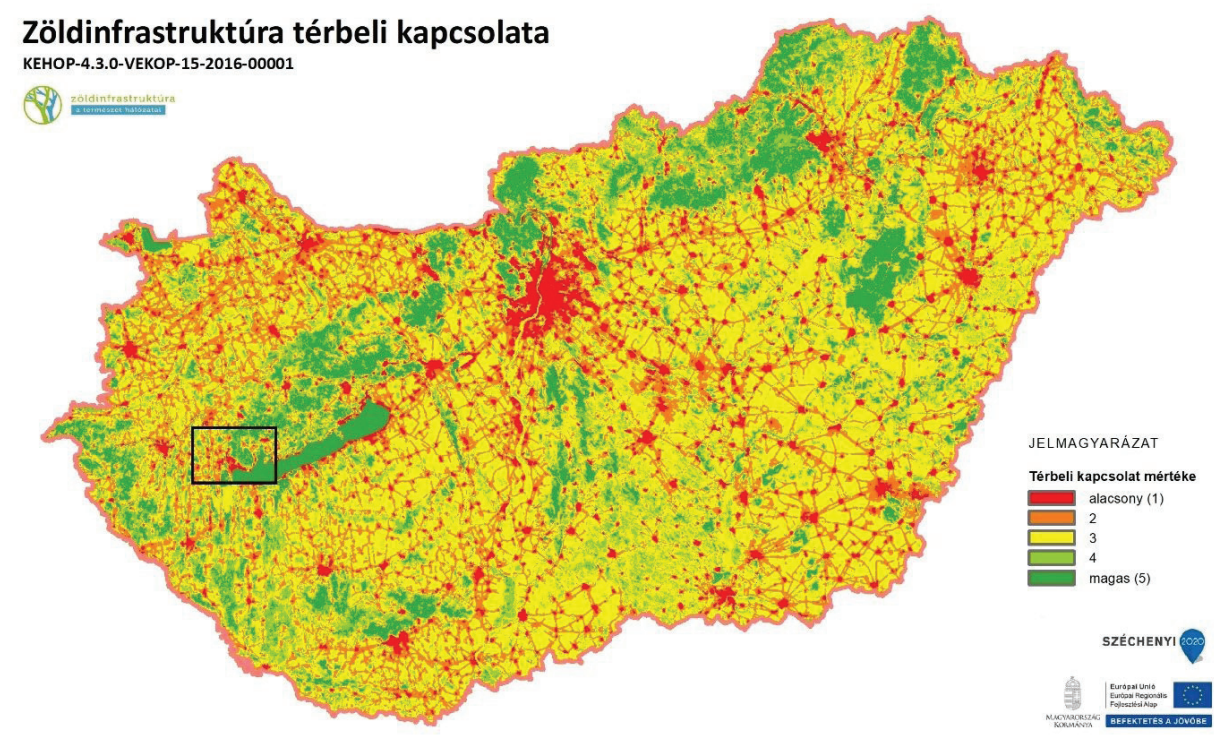

3. ábra. Hazánk térbeli összekapcsoltsága a zöldinfrastruktúra-értékelés ötkategóriájú indexe alapján.

\section{Zöldinfrastruktúra-elemek szolgáltatási szintje}

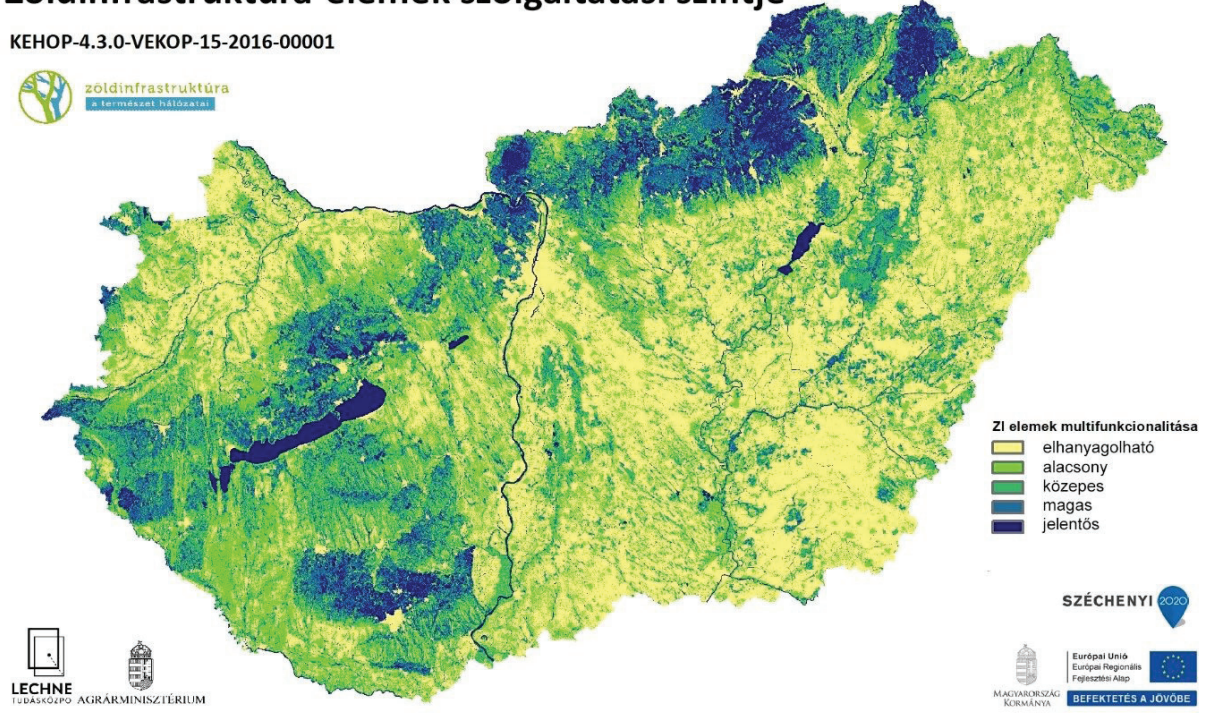

4. ábra. Hazánk területeinek multifunkcionalitása a zöldinfrastruktúra ökoszisztéma-szolgáltatásainak ötfokozatú értékelése alapján. 1 - rossz, 2 - kedvezőtlen, 3 - közepes, 4 -jó, 5 - kiváló. 
azt, hogy ezek a területek értékesebbek, viszont jól jelzi, hogy az ökoszisztémák vízerózió elleni védelme, a dombvidéki árvízi kockázatcsökkentés, valamint a potenciális szürés itt a legfontosabb ökoszisztéma-szolgáltatás.

A hármas kompozit értékelés alapján az ország területén a legnagyobb arányban (37,2\%-ban) rossz ökológiai állapotú, közepes ÖSZ-eket nyújtó, rosszközepes térbeli összekapcsoltsággal rendelkező ökoszisztémák vannak (4. Online Függelék). Aktuálisan ZI hálózati elemnek tekinthető az ország területének 49\%-a (5. ábra). A kiváló ökológiai állapotú elemek a kijelölt hálózat alig 10\%-át teszik ki. A meglévő ZI-hálózat elemei igen változatos területhasználatot ölelnek fel. A kijelölt hálózat döntő többsége, mintegy 54\%-a erdős terület. A vizes élőhelyek és a felszíni vizek a kijelölt hálózat 11\%-át, a gyepek a 20\%-át alkotják. A kijelölt hálózat 5\%-a szántóterület.

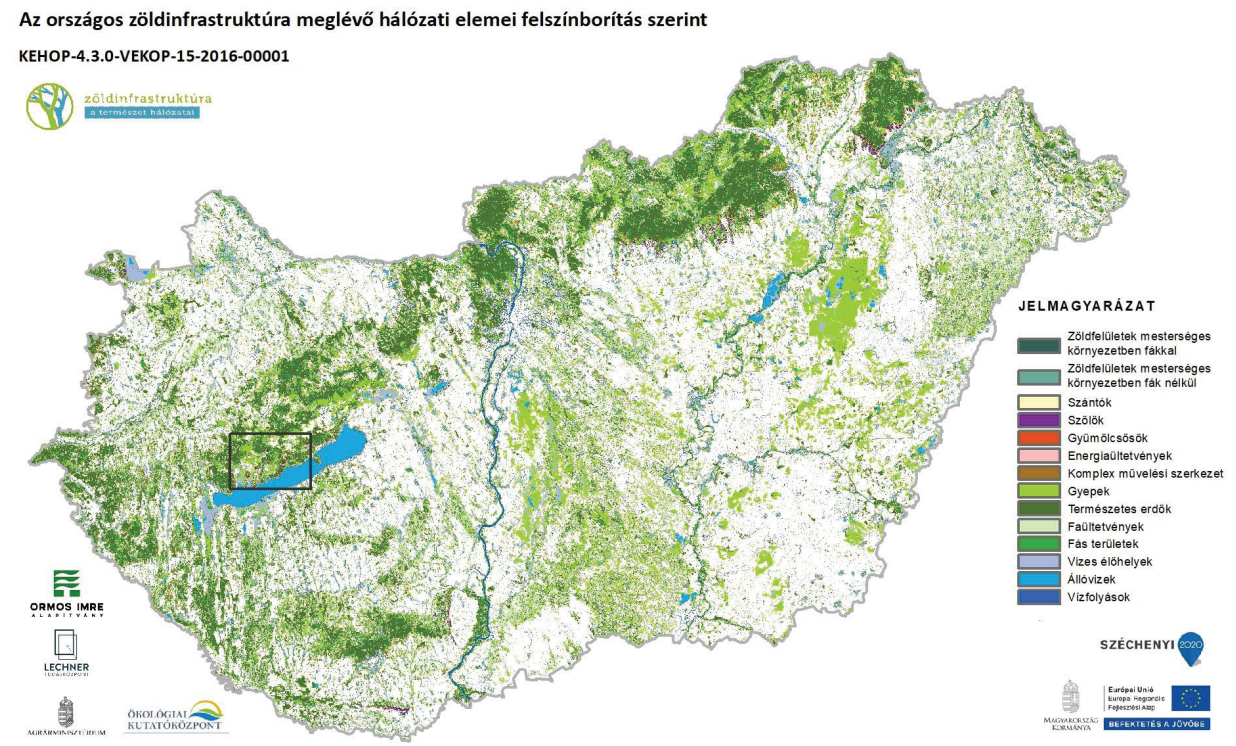

5. ábra. A zöldinfrastruktúra-hálózat meglévő elemeinek felszínborítási típusa (NÖSZTÉP ökoszisztéma típus kategóriák szerint) a hármas kompozit állapotértékelés alapján.

\section{Diszkusszió}

Jelen cikk keretében három szempont, az ökológiai állapot, a térbeli összekapcsoltság és a multifunkcionalitás alapján értékeltük a hazánk területén megtalálható ökoszisztémákat. Az alapállapot-értékelés alapján megállapítottuk, hogy az ország 49\%-a, azaz 4,5 millió hektár terület tekinthető a ZI-hálózat részének. Jelenleg hazánk országos jelentőségü egyedi jogszabállyal védett terüle- 
teinek kiterjedése 848,9 ezer hektár, míg 1,2 millió hektárnyi terület ezeken túl Európai Közösségi irányelvek alapján védett Natura 2000 terület (AM 2021). A Biodiverzitás Stratégiában javasolt 30\%-os védettségi területarány elérésének egy fontos szempontja lehet a zöldinfrastruktúra értékelés, elsősorban a javasolt ZIhálózat még nem védett, de jó vagy kiváló ökológiai állapotú elemeinek további értékelésével (COM[2011] 244 EB). A javasolt ZI-hálózatnak mindössze 10\%-a van kiváló ökológiai állapotban. A további területek indikátorértékei alkalmasak azon fenntartási és fejlesztési intézkedések meghatározására, amelyek javítják az ökoszisztémák állapotát, térbeli összekötöttségét, és ökoszisztéma-szolgáltatásait, és ezzel az emberi jóllét szintjét is növelik. A fejlesztési irányok kijelölésének módszertanával Török és munkatársai (2021) foglalkoznak.

Fontos leszögezni, hogy az eredmények pontosságát a felhasználható adatok pontossága határozza meg. Például a gyepeket nagyobb arányban soroltuk ökológiai állapotuk szempontjából kiváló kategóriába, mint az erdőket. Ezt a torzítást a gyepek állapotával kapcsolatos adathiány okozta, amit az eredmények értékelésénél mindenképpen figyelembe kell venni. Pontosabb állapotértékeléshez szükség lenne egy országos gyepkataszter létrehozására. Bizonytalanságot eredményezett az is, hogy a Víz Keretirányelvből származó vízminőségi adatok nem fedik le az összes hazai felszíni víztestet. A víztestek értékelése számos ÖSZ modellezésekor nehézségbe ütközött. A további kutatások során ezért valamennyi hazai felszíni víztest szolgáltatási értékelését további tényezők, szolgáltatások bevonásával finomítani szükséges.

A térbeli kapcsolatok minőségének és mennyiségének vizsgálata és értékelése nagy nehézségekbe ütközik, mivel a vizsgálható (és általunk is vizsgált) strukturális indexek a funkcionalitásról csak korlátozott mértékben szolgáltatnak információkat. Részletes és többnyire nehezen gyüjthető fajelőfordulási, -terjedési (pl. genetikai) adatra lenne szükség az élőhelyhálózat felderítéséhez, a barrierek, a potenciális és müködő ökológiai folyosók azonosításához. Mivel új adatok gyüjtésére és részletes modellezésre nem volt módunk, szakértői becslés alapján határoztuk meg az elemzések paramétereit. Igyekeztünk olyan beállításokat alkalmazni, amelyek általános érvényüek lehetnek, de az eredményeket valós fajelterjedési adatokon alapuló validációval szükséges ellenőrizni a jövőben.

A projekt által kidolgozott és térképezett szabályozó/fenntartó és kulturális ÖSZ-eknek csak egy részét tudtuk felhasználni a ZI-értékelésben. Ez természetesen csak tájékoztató információt adhat az ÖSZ-ek állapotáról. A tervezés további fázisában javasolt további ÖSZ-eket bevonni a ZI állapotértékelésébe. Szintén fontos megjegyezni, hogy az országos ZI állapotértékelés konkrét mintaterületi és települési tervezési döntésekhez nem minden esetben differenciál eléggé, ezért térségi és belterületi szinten szükség van további részindikátorok értékelésére is (Csőszi et al. 2021). 
Mindezek mellett eredményeink jó alapot nyújthatnak arra, hogy a környezeti fenntarthatóságra irányuló tervek beépüljenek a tervezési gyakorlatba és a területhasználattal kapcsolatos döntéshozatalba.

Köszönetnyilvánitás - A kutatás a KEHOP-4.3.0-VEKOP-15-2016-00001 számú projekt része volt, amely az ERFA finanszírozásával a Széchenyi 2020 program részeként valósult meg.

\section{Irodalomjegyzék}

AM (2021): Természetvédelmi adatok 2020. december 31-ei állapot szerint. Jelentés. Agrárminisztérium, Budapest, 95 p. https://termeszetvedelem.hu/wp-content/uploads/2021/07/Termeszetvedelmi adatok-20201231-1.pdf

Bölöni, J., Molnár, Zs., Kun, A. (szerk.) (2011): Magyarország élöhelyei. A hazai vegetációtípusok leirása és határozója. ÁNÉR 2011. MTA ÖBKI, Vácrátót, 441 p.

Csákvári E., Fabók V., Babai D., Dósa H., Kisné Fodor L., Jombach S., Kelemen E., Tormáné Kovács E., Könczey R., Mártonné Máthé K., Michalkó G., Remenyik B., Tanács E., Valánszki I., Zölei A. (2021): A gyalogos természetjárás és gombászás mint kulturális ökoszisztémaszolgáltatások értékelése - Az ökoszisztéma állapottól a ténylegesen igénybe vett ökoszisztémaszolgáltatás értékelésig. A közösségi jelentőségü természeti értékek hosszú távú megőrzését és fejlesztését, valamint az EU biológiai sokféleség stratégia 2020 célkitüzéseinek hazai szintủ megvalósítását megalapozó stratégiai vizsgálatok projekt, Ökoszisztéma-szolgáltatások projektelem. Agrárminisztérium, Budapest, 118 p. https://doi.org/10.34811/osz.rekreacio.tanulmany

Csőszi, M., Vaszócsik, V., Török, K., Kollányi, L., Schneller, K., Teleki, K., Bánhidai, A., Kiss, D., Konkoly-Gyúró, É., Jáger, K., Csecserits, A., Szitár, K., (2021): A zöldinfrastruktúra megőrzését és fejlesztését biztositó stratégiai keretek és fejlesztési célok, prioritások meghatározása, országos szintü alkalmazása. Jelentés. Agrárminisztérium, Budapest, $151 \mathrm{p}$.

De Leo, G. A., Levin, S. (1997): The multifaceted aspects of ecosystem integrity. Conservation Ecology 1: 3. https://doi.org/10.5751/ES-00022-010103

EEA (2011): Landscape fragmentation in Europe. Joint EEA-FOEN report. EEA, Copenhagen, 92 p. https://doi.org/10.2800/78322

Foley, J. A., DeFries, R., Asner, G. P., Barford, C., Bonan, G., Carpenter, S. R., Chapin, F. S., Coe, M. T., Daily, G. C., Gibbs, H. K., Helkowski, J. H., Holloway, T., Howard, E. A., Kucharik, C. J., Monfreda, C., Patz, J. A., Prentice I. C., Ramankutty, N., Snyder, P. K. (2005): Global consequences of land use. Science 309: 570-574. https://doi.org/10.1126/science.1111772

Koncz P., Horváth L., Somogyi Z., Kottek P., Weidinger T., Ács F., Kröel-Dulay Gy., Fogarasi J., Molnár A., Pásztor L., Popp J. (2021): A tüzifatermelés, az éghajlat-és a mikroklíma-szabályozás, mint ökoszisztéma-szolgáltatások értékelése - Az ökoszisztéma állapottól a ténylegesen igénybe vett ökoszisztéma-szolgáltatás értékelésig. A közösségi jelentőségü természeti értékek hosszú távú megőrzését és fejlesztését, valamint az EU biológiai sokféleség stratégia 2020 célkitűzéseinek hazai szintủ megvalósítását megalapozó stratégiai vizsgálatok projekt, Ökoszisztéma-szolgáltatások projektelem. Agrárminisztérium, Budapest, 191 p. https://doi.org/10.34811// osz.klima.tanulmany

Kovács-Hostyánszki A., Belényesi M., Geng I., Kemencei Z, Kisné Fodor L., Lehoczki R., Medveczky P., Naszádos A., Pataki R., Petrik O., Sárospataki M., Szalai M., Szekeres Á., Tanács E., 
Zajácz E. (2021): A pollináció, mint ökoszisztéma-szolgáltatás értékelése - az ökoszisztéma-állapottól a ténylegesen igénybe vett ökoszisztéma-szolgáltatás értékeléséig. A közösségi jelentőségü természeti értékek hosszú távú megörzését és fejlesztését, valamint az EU biológiai sokféleség stratégia 2020 célkitűzéseinek hazai szintü megvalósítását megalapozó stratégiai vizsgálatok projekt Ökoszisztéma-szolgáltatások projektelem. Agrárminisztérium, Budapest, 67 p. https:// doi.org/10.34811//osz.pollinacio.tanulmany

Kovács-Hostyánszki, A., Bereczki, K., Czúcz, B., Fabók, V., Fodor, L., Kalóczkai, Á., Kiss, M., Koncz, P., Kovács, E., Rezneki, R., Tanács, E., Török, K., Vári, Á., Zölei, A., Zsembery, Z. (2019): Nemzeti ökoszisztéma-szolgáltatás térképezés és értékelés, avagy a természetvédelem országos programja. Természetvédelmi Közlemények 25: 80-90. https://doi.org/10.20332/tvkjnatconserv.2019.25.80

Liquete, C., Kleeschulte, S., Dige, G., Maes, J., Grizzetti, B., Olah, B., Zulian, G. (2015): Mapping green infrastructure based on ecosystem services and ecological networks: A Pan-European case study. Environmental Science and Policy 54: 268-280. https://doi.org/10.1016/j.envsci.2015.07.009

Maes, J., Barbosa, A., Baranzelli, C., Zulian, G., Silva, F. B., Vandecasteele, I., Hiederer, R., Liquete, C., Paracchini, M. L., Mubareka, S., Jacobs-Crisioni, C., Castillo, C. P., Lavalle, C. (2015): More green infrastructure is required to maintain ecosystem services under current trends in land-use change in Europe. Landscape Ecology 30: 517-534. https://doi.org/10.1007/s10980-014-0083-2

OVF (2016): A Duna-vízgyüjtö magyarországi része - Vizgyüjtö-gazdálkodási Terv-2015. Országos Vízügyi Főigazgatóság, Budapest, 676 p. https://www.vizugy.hu/vizstrategia/documents/ E3E737A3-3EBC-4B6F-973C-5DD9B8A6DBAB/OVGT_foanyag_vegleges.pdf

Schröter, D., Cramer, W., Leemans, R., Prentice, I. C., Araujo, M. B., Arnell, N. W., Bondeau, A., Bugmann, H., Carter, T. R., Gracia, C. A., De La Vega-Leinert, A. C., Erhard, M., Ewert, F., Glendining, M. J., House, J. I., Kankaanpaa, S., Klein, R. J. T., Lavorel, S., Lindner, M., Metzger, M. J., Meyer, J., Mitchell, T. D., Reginster, I., Rounsevell, M., Sabate, S., Sitch, S., Smith, B., Smith, J., Smith, P., Tuck, G. (2005): Ecosystem service supply and vulnerability to global change in Europe. Science 310: 1333-1337. https://doi.org/10.1126/science.1115233

Tanács, E., Bede-Fazekas, Á., Standovár, T., Pásztor, L., Szitár, K., Csecserits, A., Kiss, M., Vári, Á. (2021): Az általános ökoszisztémaállapot-indikátorok térképezésének módszertana. Jelentés. Agrárminisztérium, Budapest, 154 p. https://doi.org/10.34811//osz.allapot.modszer.tanulmany

Tanács, E., Belényesi, M., Lehoczki, R., Pataki, R., Petrik, R., Standovár, T., Pásztor, L., Laborczi, A., Szatmári, G., Molnár, Zs., Bede-Fazekas, Á., Kisné Fodor, L., Varga, I., Zsembery, Z., Maucha, G. (2019): Országos, nagyfelbontású ökoszisztéma-alaptérkép: módszertan, validáció és felhasználási lehetöségek. Természetvédelmi Közlemények 25: 34-58. https://doi.org/10.20332/ tvk-jnatconserv.2019.25.34

Török, K., Csőszi, M., Vaszócsik, V., Schneller, K., Teleki, M., Kollányi, L., Keszthelyi, Á., Máté, K., Csecserits, A., Halassy, M., Kertész, M., Szitár, K. (2021): A zöldinfrastruktúra-fejlesztés célterületei Magyarországon. Természetvédelmi Közlemények 27: 158-172. https://doi. org/10.20332/tvk-jnatconserv.2021.27.158

Vári Á., Kozma Zs., Pataki B., Jolánkai Zs., Kardos M., Decsi B., Pásztor L., Bakacsi Zs., Tóth B., Laborczi A., Pinke Zs., Jolánkai G. †, Centeri Cs., Mattányi Zs., Dóka R., Fodor L., Zsembery Z. (2021): A síkvidéki és a dombvidéki árvízkockázat-csökkentés, az erózió, a szürés és az aszálymérséklés, mint ökoszisztéma-szolgáltatások értékelése - az ökoszisztéma-állapottól a ténylegesen igénybe vett ökoszisztéma-szolgáltatás értékeléséig. A közösségi jelentőségü természeti értékek hosszú távú megőrzését és fejlesztését, valamint az EU biológiai sokféleség stratégia 2020 célkitüzéseinek hazai szintű megvalósítását megalapozó stratégiai vizsgálatok projekt, Ökoszisztéma-szolgáltatások projektelem. Agrárminisztérium, Budapest, 211 p. https://doi. org/10.34811//osz.hidrologia.tanulmany 
Hivatkozott jogszabályok:

$\operatorname{COM}(2011) 244$ EB rendelet. Our life insurance, our natural capital: an EU biodiversity strategy to 2020 .

$\operatorname{COM}(2013) 249$ EB rendelet. Green Infrastructure (GI) — Enhancing Europe's Natural Capital.

\section{Függelék:}

A cikkhez tartozó Online Függelékek a folyóirat honlapján találhatóak.

1. Függelék: Az ökoszisztéma-típusok zöldinfrastruktúra ökológiai állapotértékelése során figyelembe vett indikátorai és értékelésük.

2. Függelék: A táji konnektivitás index és az effektív hálóméret index számítása.

3. Függelék: A zöldinfrastruktúra multifunkcionalitás állapotértékelésében felhasznált ökoszisztéma-szolgáltatás indikátorok.

4. Függelék. A hármas kompozit kategóriabeosztása. 


\title{
Designation and evaluation of the national green infrastructure based on a multi-criteria analysis
}

\author{
Katalin Szitár ${ }^{1}$, Mónika Csőszi², Vilja Vaszócsik², Krisztián \\ Schneller ${ }^{2}$, Anikó Csecserits ${ }^{3}$, László Kollányi ${ }^{4}$, Mónika Teleki ${ }^{2}$, \\ Ottó Petrik ${ }^{2}$, Róbert Pataki², Róbert Lehoczki², Melinda Halassy ${ }^{3}$, \\ Eszter Tanács ${ }^{3}$, Miklós Kertész ${ }^{3}$, Edina Csákvári ${ }^{3}$, Imelda Somodi ${ }^{3}$, \\ Attila Lengyel $^{3}$, Róbert Gallé ${ }^{1}$, András Weiperth ${ }^{5}$, Éva Konkoly- \\ Gyuró $^{6}$, Klaudia Máté ${ }^{4}$, Ákos Bence Keszthelyi ${ }^{4}$ \& Katalin Török ${ }^{3}$ \\ ${ }^{1}$ Centre for Ecological Research Institute of Ecology and Botany, Lendület Landscape \\ and Conservation Ecology, H-2163 Vácrátót, Alkotmány u. 2-4, Hungary \\ ${ }^{2}$ Lechner Knowledge Center, H-1111 Budapest, Budafoki út 59, \\ Hungary; H-1149 Budapest, Bosnyák tér 5, Hungary \\ ${ }^{3}$ Centre for Ecological Research Institute of Ecology and Botany, \\ H-2163 Vácrátót, Alkotmány u. 2-4, Hungary \\ ${ }^{4}$ Ormos Imre Charitable Trust, H-1118 Budapest, Villányi út 29-43, Hungary \\ ${ }^{5}$ Hungarian University of Agriculture and Life Sciences, Institute of Aquaculture and \\ Environmental Safety, Deptartment of Freshwater Fish Ecology, \\ H-2100 Gödöllö, Páter Károly u. 1, Hungary \\ ${ }^{6}$ University of Sopron, Institute of Environmental and Earth Sciences, \\ H-9400 Sopron, Bajcsy-Zsilinszky u. 4, Hungary \\ E-mail: szitar.katalin@ecolres.hu
}

According to the green infrastructure framework of the EU Biodiversity Strategy, biological diversity can be sustained if semi-natural and other landscape features fulfill their ecological functions and constitute a functioning habitat network. We assessed the state of Hungarian ecosystems based on three criteria: ecological condition, spatial connectedness, and multifunctionality. Based on our results, $49 \%$ of the country's area may be regarded as part of the actual green infrastructure network. However, only $10 \%$ of this area is in excellent ecological condition. Our indicator framework highlights the most effective measures to improve the ecological condition, spatial arrangement, and multifunctionality of the areas of poor ecological state.

Keywords: connectivity, effective mesh size, erosion control, fragmentation, pollination, recreation, naturalness, water run-off control 